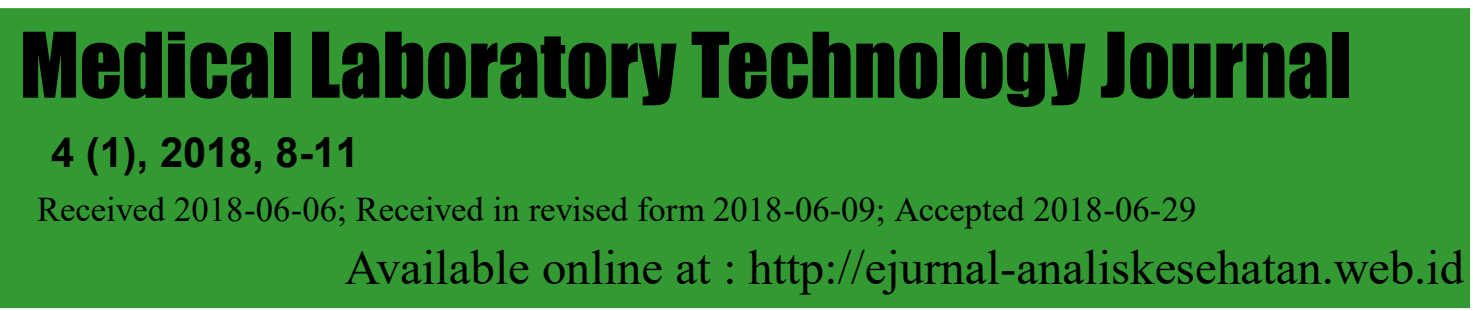

\title{
CORRELATION BETWEEN ONSET OF DIABETES MELLITUS AND NITRIC OXIDE LEVELS IN PATIENT WITH TYPE 2 DIABETES MELLITUS
}

\author{
Theosobia Grace Orno ${ }^{1}$, Mansyur Arif ${ }^{2}$, Irfan Idris ${ }^{3}$ \\ ${ }^{1}$ Department of Health Analyst Poltekkes Kemenkes Kendari, ${ }^{2}$ Department of Clinical Patholo- \\ gy Faculty of Medicine, University of Hasanuddin, ${ }^{3}$ Department of Physiology Faculty \\ of Medicine Hasanuddin University \\ e-mail: otheosobia@yahoo.com
}

\begin{abstract}
Type 2 diabetes mellitus (DM) is associated with increased risk of endothelial dysfunction if it lasts a long time without control. This study aims to connect the Onset of Diabetes Mellitus (DM) with Nitric Oxide levels in patients of type 2 diabetes mellitus. The study used cross-sectional study method. The samples were 86 subjects, consisting of 38 subjects of Type 2 DM controlled and 48 subjects of Type 2 DM uncontrolled. The results of the Kruskal-Wallis statistical test showed no significant difference between the Onset of DM and Nitric Oxide levels in the categories of 4-6 years (19.4 \pm 10.1$), 7-9$ years $(17.3 \pm 9.3)$ and $10-12$ years $(13.3 \pm$ 8.5) $(p=0.06)$. Furthermore, the Spearman correlation test revealed a negative correlation between the Onset of DM and Nitric Oxide level in patients with Type 2 DM with and without control $(r=-0.217)$. The level of Nitric Oxide (NO) can consider as a predictor of long-term complication in patients with type $2 \mathrm{DM}$.
\end{abstract}

Keywords: Type 2 diabetes mellitus; Onset of diabetes mellitus; Nitric Oxide

\section{INTRODUCTION}

The World Health Organization (WHO) defines diabetes mellitus as a collection of anatomical and chemical problems that result from some factors in which there is absolute or relative insulin deficiency and impaired insulin function associated with accelerated atherosclerosis and predisposes to specific microvascular abnormalities such as occurrence retinopathy, nephropathy, and neuropathy. diabetes mellitus Is related to increasing life expectancy, lifestyle, less physical activity and a disproportionate diet (Sugiono, 2007).

Prolonged hyperglycemia and insulin resistance experienced by people with diabetes mellitus (DM) will lead to increased polyol pathway activity in this case sorbitol, increased synthesis of Advanced Glycosylation End Products (AGEs), activation of Protein Kinase $\mathrm{C}$ (CCP) and cytokine release by adipose tissue. The activity of these various cellular pathways will lead to physiological disorders and damage to vascular endothelium (Beckmen, 2008). Endothelial dysfunction is defined as an imbalance between relaxation and contraction factors, between procoagulant mediators and anticoagulants or between substances that in- hibit and promote growth (Personal et al., 2008).

Changes in endothelial function in patients with DM has widely proven both invitro and invivo. Research by Jansson et al (2009), in patients with coronary heart disease (CHD) occurs endothelial dysfunction characterized by an increase in the production of various compounds that are prothrombotic and vasoconstriction such as Tissue Factor (TF), Von Willebrand Factor (vWF), Platelet Activation Factor (PAF), endothelin, Thromboxane A2, Plasminogen Activator Inhibitor-1 (PAI-1). Similarly, studies conducted by Widiastuti (2012), in patients with CHD and without diabetes mellitus showed a decline in the production of antithrombotic compounds and vasodilatations such as Nitric Oxide (NO), thrombomodulin, and Tissue Plasminogen Activator (TPA). Presumably the role of $\mathrm{NO}$ in the process of $\mathrm{CHD}$ occurrence due to atherosclerosis through the mechanism of endothelial dysfunction, where $\mathrm{NO}$ is an important mediator that can act as free radicals and can turn into peroxynitrite formed by neuronal cells that modulate neurotransmission in endothelial cells and stimulate the relaxation/dilatation of blood vessels. 
Decreased NO levels occur due to decreased NO synthesis or increased degradation resulting in superoxide anion production resulting in decreased inhibition of atherogenic and thrombogenic processes and decreased the ability of coronary artery dilatation (Zieman SJ, 2008). Although the study by Kumar $V$ et al., 2009 shows that there is an increase in NO levels in CHD patients but on the other hand some experts argue that NO levels play a role as a marker of endothelial dysfunction and are not independent coronary risk factors (Paul W et al., 2011).

People with diabetes are expected to conduct regular tests and treatments to monitor their metabolic status, as a guideline for monitoring controlled DM therapy if $\mathrm{HbA} 1 \mathrm{c}$ levels $<7 \%$. According to The Diabetes Control and Complications Trial (DCCT), the presence of good glycemic control can slow the development of early complications of diabetes, one of which is endothelial dysfunction characterized by a decrease in the value of nitric oxide (NO) (McPhee, 2010). Research conducted by Erick et al. (2007), showed that low $\mathrm{HbA} 1 \mathrm{c}$ in patients with $\mathrm{DM}$ have a low risk of occurrence of microvascular complications.

Research on levels of $\mathrm{NO}$ in patients with DM by onset is not yet fully the attention of researchers. Whereas long-term hyperglycemia affects endothelial function with the activation of various pathways both sorbitol, AGEs, and PKC which leads to decreased NO role as a potent vasodilator or $\mathrm{NO}$ in the form of Endothelial Nitric Oxide System (eNOS) which functions as anti-inflammatory and antithrombosis (Chan N, 2008). Therefore, this study aims to link the onset of diabetes mellitus with nitric oxide levels in patients with type 2 diabetes mellitus.

\section{MATERIAL AND METHOD}

This research is one of the competencies of medical laboratory technology in the field of clinical chemistry. This type of analysis is analytical research using Cross-Sectional design. The study was conducted from July to November 2016 at the Clinical Pathology Laboratory of Hasanuddin University Hospital (RSUH) Makassar.

The samples of this study were adults, men and women who came to Hasanuddin University Hospital (RSUH), Makassar and diagnosed with Type 2 DM by the clinician.
Willing to check Nitric Oxide (NO) and meet the criteria inclusion is not taking anticoagulant / antiplatelet drugs (eg.heparin) as well as antioxidants such as vitamin C, not acute / chronic infections characterized by Blood Endapode (LED) $<15 \mathrm{~mm} / \mathrm{h}$ for men and $<20$ $\mathrm{mm} / \mathrm{h}$ for women, diabetic ulcers, history of stroke and other cerebrovascular diseases, pregnancy.

The patient's venous blood has been taken three ccs using a vacutainer and Separating Tube (SST) serum tube, the separator gel contained in the SST tube will speed up the serum separation process from the blood cells when centrifuged at $3000 \mathrm{rpm}$ for 10 minutes.

Measurements of $\mathrm{HbA} 1 \mathrm{c}$ levels have made by inserting $500 \mu \mathrm{l}$ serum samples into the $\mathrm{HbA} 1 \mathrm{c}$ cassette. Total $\mathrm{Hb}$ is measured colorimetrically. NO levels have been determined using a spectrophotometric method with Griess reaction principle, i.e., NO examination by way of indirectly by spectrophotometric. This examination involves the enzymatic conversion of nitrate to nitrite, by the enzyme $\mathrm{Ni}$ trate Reductase, followed by the colorimetric detection of nitrite as a dye-colored azo dye product of a Griess reaction absorbing $540 \mathrm{~nm}$ visible light.

To see the difference of Nitric Oxide content in the three categories of DM Old (4-6 years, 7-9 years and 10-12 years) analyzed by Kruskal Wallis Test because the data was not abnormal distributed and for Old DM Correlation Test with Nitric Oxide content was analyzed with Spearman Correlation Test. For other data analysis using categorical variables done with the Descriptive test. The results of a study are said to be significant when the value of $p<0.05$.

\section{RESULTS AND DISCUSSION \\ Characteristics of the sample}

The number of samples that participated in the study was 86 samples consisting divided into several categories: 
Table 1. Characteristics of Participants

\begin{tabular}{lccc}
\hline & Characteristics & Volume $(\mathbf{n}=\mathbf{8 6})$ & Persentation(\%) \\
\hline Gender & Male & 34 & 39.5 \\
& Female & 52 & 60.5 \\
\hline Ages & $40-45$ & 11 & 12.8 \\
(year) & $46-50$ & 15 & 17.4 \\
& $51-55$ & 18 & 20.9 \\
& $56-60$ & 16 & 18.6 \\
& $61-65$ & 11 & 12.8 \\
& $66-70$ & 14 & 16.3 \\
& $71-75$ & 1 & 1.2 \\
\hline Onset DM & $4-6$ & 26 & 30.2 \\
(year) & $7-9$ & 37 & 43.0 \\
& $10-12$ & 23 & 26.7 \\
\hline
\end{tabular}

\section{Multivariate Analysis}

After the Kruskal-wallis test $(p=0.06)$ it can be said there is no significant difference between Onset DM of each category with $\mathrm{Ni}$ tric Oxide content.

\section{Table 2.Comparison of DM Onset to NO Levels in Type 2 DM}

Table2.Comparison of DM Onset to NO Levels in Type 2 DM

\begin{tabular}{ccccc}
$\begin{array}{c}\text { Onset DM } \\
\text { (Tahun) }\end{array}$ & $\mathbf{N}$ & $\begin{array}{c}\text { Median } \\
\text { (minimum - } \\
\text { maksimum) }\end{array}$ & $\begin{array}{c}\text { Rerata } \pm \\
\text { S.D }\end{array}$ & $\boldsymbol{P}^{*}$ \\
\hline $4-6$ & 25 & $20(5.4-36)$ & $19.4 \pm 10.1$ & 0.06 \\
\hline $7-9$ & 37 & $14.6(5-34)$ & $17.3 \pm 9.3$ & \\
\hline $10-12$ & 23 & $11(4.8-32)$ & $13.3 \pm 8.5$ & \\
\hline
\end{tabular}

Spearman correlation test results also indicate negative correlation $(r=-0.217)$ between Onset DM and Nitric Oxide (NO) level in Patient DM Type 2 but have weak correlation strength.

Table 3. Correlation between Onset of DM and Nitric Oxide Levels in Type 2 DM

\begin{tabular}{lll}
\hline & & NO \\
\hline Onset of DM & $\mathrm{R}$ & -0.217 \\
& $\mathrm{P}$ & 0.046 \\
& $\mathrm{~N}$ & 86 \\
\hline
\end{tabular}

$R=$ coefisiencorelation. $P=$ sianification levels. $N=$ volume

The age range of DM Type 2 subjects in this study was $40-75$ years (table 1 ). Other studies have revealed the same thing, Ananta et al (2000), discloses similarly, that generally, 23 people with a mean of NO $13.3 \pm 8.5$. Type 2 DM occurs after the 4th decade. Wild There was a significant difference between et al. (2004), in his article, mentions that the each group of Old category of DM to NO $(p=$ estimated number of diabetic subjects in 2030 0.06), but weak correlation strength $(r=$ will increase and the largest age group re- 0.217) (table 2 and table 3). Previous studies mains between 40-70 years, both in develop- conducted by Widiastuti et al. (2012) in CHD ing countries and around the world. Research subjects with and without Type 2 DM showed conducted Handayani et al. (2003), in Sema- that CHD subjects with DM had a lower NO rang concluded that the age of more than 45 value. NO levels, in theory, correlate with the years has a risk of having type 2 diabetes by incidence of endothelial dysfunction.
7.5 times compared with those aged less than 45 years. As already known, there are three critical factors related to DM pathogenesis: (1) genetic factors, (2) pancreatic beta cell disorders, and (3) decreased insulin activity in insulin-sensitive tissues, including skeletal muscle, liver, and fat mass. Insulin resistance in Type 2 DM is not very clear, but the following factors play a significant role: obesity, low-fat carbohydrate and low physical activity that are common in 40-year-olds, a risk factor for Type 2 DM.

The number of DM Type 2 subjects not controlled more than the controls. This condithus gives the impression of high-risk facfor the development of diabetes complicaand uncontrolled Group 2 DM divided by $\mathrm{HbA} 1 \mathrm{c}$ levels by Perkeni (2011), defined $\leq 7 \%$ controlled category and $>7 \%$ in the open category. Use of $\mathrm{HbA} 1 \mathrm{c}$ in diabetes to monitor long -term blood glucose, so as to predict the development and progression of microvascular complications. Uncontrolled diabetes mellitus will increase free fatty acids and insulin reincrease NO catabolism. Insulin increases the activity of nitric oxide system (NOS) by stimulating phosphotidylinositol-3 kinase and Akt kinase. Signal transduction with insulin via the phosphotidylinositol-3 kinase pathway in insulin resistance patients is impaired. Insulin stimulates NOS to be less and NO production decreases, resulting in more endothelin produced and an increase in inflammation and thrombosis (Sargowo D, Rohman S, 2008).

Duration of DM in this study divided into 3 groups of category 4-6 years 25 people with average rate of $19.4 \pm 10.1,7-9$ years old as many as 37 people with the average price of NO $17.3 \pm 9.3$, and $10-12$ years as many as a 
NO has three isoenzymes; two of which Kumar, V., et al. (2009). Intensive Blood Glustrictly related to the rate of thrombosis. IsoenzymeeNOS (endothelial nitric oxide synthase) expressed by both platelet cells and endothelial cells, but quantitatively derived from endothelial cells is much greater. IsoenzymeeNOS is essential in the regulation of platelet function (release of substance) to determine the physiological and thrombotic balance, while iOSisoenzymes (inducible nitric oxide synthase) have remodeling effects on blood vessels (Chan. et al., 2012). It's just because of limitations and technical reasons; these two isoenzymes cannot be analytical researchers, so only NO total studied in this study.

\section{CONCLUSION}

There was no significant difference between Onset DM and Nitric Oxide (NO) levels for each category $(p=0.06)$, and there was a negative correlation between DM onset and Nitric Oxide (NO) level in patients with Type 2 DM but correlated strength the weak $(r=$ 0.217 ). Nitric Oxide (NO) content may be considered a predictor of long-term complications in patients with type $2 \mathrm{DM}$.

\section{REFERENCES}

Ananta, A., \& Adioetomo, S. M. (2000). Perkembangan penduduk Indonesia menuju tahun 2015. Jakarta: Lembaga Demografi Ekonomi UI.

Beckmen, J. A. (2008). Diabetes and atherosclerosis: epidemiology, pathofisiology, and management. 5th Ed. (L. W. \& Wikons, Ed.). Philadelphia.

Chan, N. (2008). Fungsi eNOS Sebagai Anti Inflamasi dan Anti Thrombosis. Jakarta: EGC.

Erick, S., at al. (2007). Hubungan kadar HbA1c dengan risiko terjadinya komplikasi mikrovaskuler. Universitas Indonesia.

Handayani, S. A., at al. (2003). Faktor-faktor risiko diabetes mellitus tipe 2. Universitas Diponegoro Semarang.

Janson, P., at al. (2009). Endothelial disfunction. International Medical Publication, 11, 4-6.

Kilpatrick E.S., Rigby A.S., Atkin. S. L. (2007). Variability in the relationship between mean plasma glucose and $\mathrm{HbA} 1 \mathrm{c}$ : implication for the assessment of glycemic control. Journal of Clinical Chemistry, 53 (5), 897-901. 